\title{
Perceptions of English Teachers in Turkey and Germany
}

\author{
Sibel İnci ${ }^{1, *}$, Sevilay Yıldız ${ }^{2}$ \\ ${ }^{1}$ Department of Foreign Languages, Kocaeli University, Turkey \\ ${ }^{2}$ Department of Curriculum and Instruction, Abant İzzet Baysal University, Turkey
}

Copyright $\odot 2019$ by authors, all rights reserved. Authors agree that this article remains permanently open access under the terms of the Creative Commons Attribution License 4.0 International License

\begin{abstract}
We can assert that teachers have a key role for the success of program implementations. Also, the compatibility of beliefs and pedagogical practices of the teachers is significant. Analyzing the perceptions of teachers on programs in different countries may provide us with comparative lenses to comprehend how primary English programs are applied in each country and teachers' beliefs about English teaching. Therefore, the aim of this study is to compare the perceptions of English teachers on primary school English programs in Turkey and the states of Germany (North Rhine-Westphalia, Baden Württemberg and Berlin). This is a qualitative case study based on data from the perspectives of teachers. Semi-structured interview form was used with the study group including primary school English teachers in Turkey and Germany. On the basis of data, it can be concluded that teachers in Turkey are not trained to teach children and do not get sufficient support for professional development whereas the teachers in Germany are class teachers with English degrees, because the teacher trainings in these countries are different. In addition, while the teachers in Turkey experience difficulties with various reasons, English teachers in Germany have no difficulty in implementing the English programs overall.
\end{abstract}

Keywords Primary School English Program, Program Evaluation, Comparative Education, English Teaching

\section{Introduction}

Although it has been a controversial issue among the linguists, educators and countries whether 'earlier is better' $[1,2]$, teaching a foreign language to children is 'a global phenomenon' [3]. The aims of early language teaching are increasing the immersion time and getting benefit of physiological advantages. However, this hasty implementation of foreign language education into primary school curriculum across the countries needs to be scientifically proven for its long-term effects in all aspects [4] since the majority of research is still conducted in ESL contexts but EFL contexts is less relatively [3] and the results do not generally demonstrate success in every country with different reasons.

In accordance with the global spread of English, although the countries around the world have introduced English into primary level in order to be competitive within a global economy for individual and national development $[5,6,7,8]$. Developing countries with different language systems and geographically distant from English speaking countries generally have lower skills of English and the implementations of the prescribed programs are problematic compared to many European countries. According to the results of the global exams like International English Proficiency Index (EF) Turkey, South American countries and some of Asian countries have 'low' or 'very low' skills $[9,10,11,12,13]$. On the other hand, German-speaking countries such as Austria, Germany and Switzerland have higher English levels in the 18-20 age range than older age groups, and that English education is more effective in recent years [14]. Germany, one of the good examples in Europe, is more successful in EF ranking 9th with 'high proficiency' compared to Turkey ranking 62nd with 'very low' proficiency and also other Asian and South American countries in 2017 [10]. In Turkey, teaching English to children is not effective enough although it has been 20 years of the implementation and a new program was introduced which lowered the age of learning English. Therefore the studies on teaching English to children is still a field needs to be searched and one of the main elements of this issue is teachers and what their beliefs about teaching English and especially teaching English to children.

The impact of teachers' beliefs can be said one of the basic elements of teaching languages based on the active role of decision making in class $[15,16]$. Investigating the various cognitive dimensions of teachers' knowledge representing the nature of their teaching may play a fundamental role for the effective implementations. Pope 
[17] uses the term "teacher thinking" for teachers' beliefs and states that there are several different theoretical concepts used in educational research field. These are "teacher's understanding", "teacher constructs", "metaphors/ beliefs", "teacher's perspectives", "script/ schema", "plans". As Borg [15] states most of the studies on teachers' beliefs are not investigating teachers' cognition, but focus on broader aspects such as change, planning, and decision making. It can be said that all these concepts directly linked to each other as they show what happen in the classroom. Therefore in this study we prefer to use the terms "beliefs" for the concept what actually teachers think about English teaching and the difference between what they do in the school environment and "perception" as a general concept how teachers perceive the programs in general. Pope [17] defines teacher's beliefs as how teachers adjust and give meaning to the educational environment within their schools and the researcher's attempt to understand and interpret them. Burns [18] states that the beliefs of teachers are motivating factors in the classroom interactions and they represent the learning and how it takes place in the classroom. This concept dates back Kelly (1955) who proposed the usage of grid technique which allows teacher's to use their languages, beliefs about classroom practices and using this tool give a "picture" of what the teachers do in the classroom and how they make their decisions [19]. During 1990's there occurred many scholars researching and theorizing on this concept $[20,21,22,23,24,25,26,27]$. Studies on beliefs of teachers in relation to language teaching argues that teacher's own experience as learners are powerful factors which can be both positive and negative [21]. Pajares [22] thinks that the beliefs of teachers may act as a filter through the new experiences of the teachers and Johnson [23] states that pedagogical decision making of the teachers is affected strongly by their beliefs. Richardson [24] shows that the beliefs and practices can affect each other. However, Pickering [16] states that these beliefs generally resist changing. There is a group of studies investigated the link between teachers' beliefs and classroom practices to get an idea of the perceptions of teachers on curriculum and especially curriculum reforms [28,29,30,31]. These studies show that there is a tension between the beliefs of the teachers and approaches of the new programs. Also there are reviews done on teachers' beliefs $[24,32,33,34,15,35]$. In one of the reviews, Richardson [24] states that the studies on perceptions and beliefs of the teachers show that teacher candidates have strong beliefs on the base of their student life, because the experience as a student is important to set the images of teaching. So changing their beliefs during teacher education is more difficult than the teachers because the teachers have classroom experience so when they face dilemmas they can change at least some of their teaching practices.

Teachers' beliefs are their perspective on how they engage in pedagogical practice [29]. However, generally the stated beliefs of teachers about language learning do not reflect their practices with different constraints; they are consistent with deeper, more general beliefs about learning [36] therefore, program implementation is not always in balance with the designed program [37]. Some of the studies on teaching English in Japan, China, Bangladesh, Korea, Taiwan, Turkey, Chile, Malaysia, Libya, Philippines declare that teacher's belief is one of the most significant reason why the program implementation fail most of the time. They argue that the teachers are generally indifferent and resist the reforms because they start the implementation of the new program without any idea and contribution or participation but with materials and the textbooks distributed by the Ministry of National Education (MONE) to teach as prescribed since the program change policies are generally top down processes $[38,39]$. Therefore the implementations mostly affected by the beliefs of the teachers. Even if the policy underlined to develop communicative skills, teachers have more traditional practices and they do not use communicative and student-centered approaches with an expected level $[40,41,42,43,44,45,46]$. Also, there is a strong tension between new English language teaching course books with communicative language teaching activities and established grammar-translation teaching practices [38]. A study in Malaysia points out although the teachers are urged to adopt communicative approaches; the main pedagogy of the teachers was rote, recitation, instruction and exposition that limited opportunities for students to participate in dialogue and discussion [42]. Teachers only focus on reading, grammar and vocabulary and teaching based on their experience $[38,39,40,41,42,43]$. Also there is lack of necessary professional support and instructional materials to affect and improve the beliefs of the teachers $[44,46,47,48,49,50,51]$. In Philippines curriculum reform study reveals that the curriculum design is not compatible with teaching situation and also the professional support and instructional materials have not been provided to the teachers [50]. In a study of English secondary teachers' perceptions of and implementation of the new English curriculum reform in China shows professional and psychological challenges of teachers and the lack of support school administrators and the backwash effect of the examination culture of China [30]. Another study in Turkey on English teachers' views on the English language curriculum of the 2nd grade of primary education finds that English teachers experience difficulties in implementing the program because of inappropriate textbook, overcrowded classrooms, insufficient lesson hours and lack of in-service training [52]. A study in Korea evaluating the teacher education gives clues about the implementations and the teacher candidate declare largely theory-oriented pre-service teacher education programs are not useful and the there is a wash back effect of the Korea Scholastic Aptitude Test on their education [53].

Interviews with teachers to have in-depth understanding 
can give detailed picture of the beliefs of the teachers. This data can be the predictor for the necessary precautions to be taken. Moreover, evaluations of the program can be done with teachers' perceptions in different countries with comparative lenses. Therefore, it is aimed to have a general understanding of the implementation of English lesson program in Turkey and Germany and their beliefs about English teaching by comparing teachers' perceptions. In this context, in response to the general problem of 'What are teachers' perceptions on primary school English programs in Turkey and the states of Germany (NRW, Baden Württemberg and Berlin)?' The following sub-problems were searched:

(1) How do Turkey and Germany primary school teachers evaluate English programs in general?

(2) How do they implement the programs?

(3) What are the problems they have while applying the programs and what are the recommended solutions for these problems?

Although Turkey and Germany in this study have different context with their history, governing and sociological background, the reason why perceptions of English teachers in Turkey and some of the states in Germany were compared had some justifications. First, Germany is a member and Turkey is a candidate country of European Union (EU) and applying the EU criteria in education. According to the EU language policies they both use the same Basic User Level (A1) of Common European Language Framework (CEFR) to prepare the English teaching programs for primary level $[54,55,56]$. Furthermore, Germany is one of the successful countries in English proficiency exam. Last but not least, the comparison of perceptions of teachers in Turkey and the states of Germany may provide some practical solutions as they have different English language teacher training approaches in terms of the theory and practice and different educational philosophies at least in practice which may lead different beliefs. Therefore, first English teacher training and English teaching at primary level in Turkey and Germany should be examined.

\subsection{English Teacher Training in Turkey and Germany}

Teacher training is the one of the crucial elements of successful English teaching. Turkey and Germany have different training systems. In Turkey, the main source for English teacher is a Bachelor program of Department of English Language Teaching and also those who graduate from the Faculty of Literature and the Faculty of Arts and Sciences can be assigned as English teachers as long as they get a pedagogical formation. Teachers are assigned by Ministry of Education of Turkey.

On the other hand, in Germany, 200 years of traditional teacher training system differs depending on the provinces but generally consists of two stages. The first stage ends with the First State Examination. The students who succeed should teach about 2 years in the second stage. At the end of this process candidates must pass the Second State Examination to be a teacher [57,58]. Due to the standards that the Bologna Process tried to establish in higher education in Europe, Germany made a reform and introduced Bachelor and Master's degrees at German universities [58,59,60,61]. In Bachelor program, the students finish 3 year undergraduate degree with school experience on the third year and are decided whether they are suitable for teaching. If they are eligible, they have master education for 2 years.

In Germany, the teachers are trained as class teachers and they study at least two disciplines during their education whereas in Turkey they study English and pedagogy in general. Therefore, the teachers in Germany teach at the primary school when they finish their studies but in Turkey, they teach at every level from primary to university. In both counties, there are also some teachers who study different disciplines like Biology, Mathematics and they are hired as English teachers when there is shortage. In Turkey, the teachers without formal English teaching qualifications are the ones who study different disciplines in English at university but they have no experience in teaching English. In Germany, they are chosen from class teachers and need to have level of $\mathrm{C} 1$ (CEFR) in four language skills and have to attend a 60 hour-course of English teaching methodology to teach English at the primary level [40].

\subsection{English Teaching at Primary Level in Turkey and Germany}

Turkey, in spite of its size and diversity, has one of the most centralized education systems in the world and all decision-makings are centralized by MONE [62]. Because of the context of globalization in general and European Union in particular English language education was introduced into primary schools in Turkey first in 1997 at 4th grade (9-10) and then by lowering the age in 2012 started at 2 nd grade (7-8 years) $[56,63]$. It was proposed to move from the traditional methods to the communicative approach to use the language functionally and also the student-centered education approach was underlined in 1997 [63]. The general purpose of the first years of English language program is to make students enjoy learning foreign languages, to rely on them as they learn a foreign language and to make them realize language learning is an enjoyable process [56]. The program emphasizes the importance of starting language learning at an early age in terms of lifelong learning and positive attitude development, and it is necessary to create a fun and motivating learning environment. It is suggested using authentic materials, drama, role-playing methods suitable for this age group. In the 2nd and 3rd grades, listening and speaking skills are given. Writing and reading skills are left for later years [56]. 
In German Federal Government consisting of 16 provinces, both the federal government and the states have sovereign rights on education [64]. Each province is responsible for its own program, and educational decisions are made by local institutions [65]. In Germany, English teaching starts at $3 \mathrm{rd}$ grade in general but in six provinces at 1 st grade $[55,66]$. English programs aim to expand the knowledge of children about other cultures and to understand their differences and similarities. Thus, a clear stance towards different languages and cultural communities is being promoted to avoid prejudice [55]. In Germany, the lessons are skill-based with real life situations, authentic language and action based methods. Functional communication competence includes listening, speaking, reading (comprehension) writing and linguistic tools $[55,65]$. School principals are responsible for the implementation of the programs and the general framework is shaped to allow teachers to apply their own methods.

\section{Method}

This study is a comparative education study conducted as a qualitative holistic multiple case study on the basis of teacher perspectives. In this study, as discussed in the importance of the study the failure of Turkey in teaching English is one of the singular cases; Germany's success in English teaching is considered as another singular case to be compared according to the perceptions of teachers. This research is limited with the opinions of experts referred to in the design of data collection instruments; qualitative data collection tools such as documents and interviews; English teaching programs and interviewed teachers with respect to the sample.

The study group included primary school teachers in Turkey (Kocaeli, Bolu and Adapazarı) $(\mathrm{n}=11)$ graduated from English Teaching, English Teaching (Open University), American Culture and Literature, English Culture and Literature, Biology, History with 3-16 years of experience and 16-24 work load and the interviews took 30-100 minutes. In Germany (NRW, Baden Württemberg and Berlin) ( $\mathrm{n}=7)$ teachers graduated from Bachelor or Pädagogische Hochschule with at least two disciplines like German, Maths, Ethics, Sports, Religion, Music, French, Geography with 2,5-30 years of experience and 15-28 work load and the interviews took 30-70 minutes. The interviews were held in 2014-2015 and 2015-2016 academic years. During the collection of qualitative data of the study, in the selection of countries purposive sampling method was used as it was justified in the importance of the study. The study group of schools and teachers in Turkey was determined with convenience sampling method, as the central programs provided by the MONE are applied in all primary level. In Germany as there are 16 states, snowball sampling method was used in the selections of the states, schools and teachers. Two schools in each state were identified in NRW, Baden Wurttemberg and in Berlin with the advice of the experts and the teachers.

\subsection{Data Collection Instrument and Data Analysis}

After the confirmation held from the ethics committee of the University, necessary permission was provided by MONE in Turkey and school administrations in Germany. Semi-structured interview form developed by the researchers was used for the interviews. The form has descriptive information questions and 3 parts to evaluate the perceptions of the teachers on the implementation of the primary English program. The teachers were asked 4 open-ended questions to examine the program overall; 15 questions for how they implement the program and 4 questions for possible problems of the implementation and solutions. Yet, the interviewer did not always depend on the questions and let the teachers talk about their perceptions freely. The semi-structured interview form used in the interviews is in Appendix 1. In this article some of the most important results are presented related to each group of the questions in the form. The form was checked before the study by three curriculum designers, two in Turkey and one in Germany to improve credibility. After a pilot study, translation into English was done and controlled by three English teachers in Turkey. One of the researchers went to a university in Germany for two months. This led to a chance to spend time on the field and engage in in-depth interviews. Interviews with teachers in Turkey were conducted in Turkish as the teachers were more comfortable to speak in their native language but in Germany they were conducted in English since one of the researchers and interviewed teachers were English teachers. The interviews were conducted face to face and recorded with the permission of the teachers to ensure credibility and accuracy.

A descriptive analysis method was used to analyze the data obtained from the interviews. The qualitative study data analysis was done according to Creswell's method [67]. The raw data in Turkish and English were read from beginning to end several times. First, the data was arranged in a logical way according to the predetermined themes and categories. Then, subcategories were defined under the themes and categories, translated into English and were checked by two English teachers. The obtained data were coded separately by 3 faculty members who are experienced as researchers. The formula of proposed by Miles and Huberman [68] was applied. According the formula, the acceptance intervals of the reliability coefficient ratios in the field literature are given as $.70, .80, .90$. As a result of the analysis, the percentage of correspondence was calculated as $81 \%$ in the encodings which indicated that the coding was reliable. Then the interpretations are correlated with and supported by 
previous studies and literature. For comments and citation, the teachers were coded with the initials T and G (Turkey and Germany), and each teacher was randomly numbered within the country $(\mathrm{T} 1, \mathrm{G} 1)$. These directives were used in the encodings.

\section{Findings and Discussion}

\subsection{How do English Teachers in Turkey and Germany Evaluate Programs in General?}

In this part, the answers of the teachers to program evaluation in general are analyzed. The related questions are about the philosophy, approaches of the program and their experience in English teaching to children. Also, the teachers first asked whether they checked the program. Some of the teachers admitted that they did not see the program and they used the course books while implementing the program, which was remarkable. They added that the books were designed according to the program so they claimed that they were aware of what the program expected.

In our study, it seems that most of the English teachers in both countries believe that the programs are progressive and humanistic in theory. One of the teachers in Turkey said "My goal as a teacher is to give love of English" (T1). A teacher from Germany stated "... the goal is just practicing speaking without any negative feelings... just try some experience for new language to get to know the World of a new language" (G5). On the other hand, in Turkey, one teacher explained the philosophy of the program as constructivist in definition "It aims to make students talk and learn by living" (T4). However, the same teacher stated that in practice it was not her approach. She thinks she has to give grammar rules and writing is a must. She said:

"When I say no grammar, yesterday I had to teach a-an, I had to do grammar. For example, we will not have a notebook the program says but we have it, because they are not able to keep it in mind. At least, I think it should be something that you can find a reference when you revise. I cannot say that I apply that philosophy very much, at least in the sense of grammar" (T4).

The beliefs of teachers in teaching grammar may not be compatible with expository grammar presentations, de-contextualized grammar work, mechanical grammar practice, gap-filling exercises and whole-class oral practice but the implications may be totally different than their beliefs [36]. As Cameron [5] states, it is not suitable to give grammar for children under 9-10 as they can develop the 'sense of patterns and regulations' of English with discourse and vocabulary. She adds that writing, even just copying may take long time physically and no mental space left to understand the meaning and usage. Especially in Turkey, it can be asserted that few of the teachers may not be aware of that the program is constructivist and based on communicative approach. Their practices may be different since their deep beliefs are not compatible with these approaches because language teaching in Turkey was not based on communicative approach until 1997 [63]. On the contrary, in Germany there is a strong emphasize on humanistic approach and also on communicative and Total Physical Response (TPR) methods as teaching languages in Western Germany went communicative in 1970s [69]. One of the teachers in Germany said:

"We have learnt that you only have to speak in English that you work with face, your mimics ... I show them what I want, when I say open your book, I have got a book I do it" (G3).

Young learner teachers of English need to understand how children think and learn and they should speak English whole lesson so they are expected to be a fluent speaker and be capable of teaching initial literacy in English [5]. However, in Turkey English teachers are not class teachers so they are not well equipped with pedagogical knowledge of children. In terms of competence for teaching English to children half of the English teachers in Turkey said they gained experiences in classroom. One of the teachers in Turkey stated:

"I am competent because of the training and the experience of last year, for example, success level in test exams or I taught the 3rd grade last year and now when I teach the 4th grade this year, I believe that their bases are sufficient when we control ourselves" (T3).

Due to the lack of qualified teachers, countries that practice teaching English for early age groups often have to rely on unqualified classroom teachers or teachers who have not been trained to provide early age group training or teachers of other areas [70]. There is already a huge shortage of English language teachers and it is expected to increase greatly in Turkey [71]. Kurkgöz [63] stated that in early 1997, language teachers in Turkey had difficulties in terms of teaching this age group. Many of the teachers did not have any teaching skills for the age group in the 4th and 5th grade, because they were trained in the age range of 12-18 years. Teacher candidates are taught only a course called 'Foreign language teaching for children' for 2 semesters at university if they are graduated from foreign language teaching departments. However, those who are not graduated from foreign language teaching take only 'educational science' courses in a-year-pedagogical formation education, which is provided from education faculties.

As long as a class teacher is a qualified foreign language teacher and can speak the language, the implementation can be a relatively easy [72]. As almost all of the English teachers in Germany are class teachers, they said 'I am qualified' to teach young learners. In this respect, it can be said that the English teachers in the 
German states know both the pedagogical characteristics of the children and they have proficiency in English. Moreover, they are given more long-term practice training at school so when they start teaching, they already have experience.

All English teachers in Turkey stated that they did not have adequate support for teaching English to children. Normally, In Turkey, in-service training is not routinely mandatory. One of the teachers from Turkey stated " 6 or 7 years ago, the (in-service) training was not especially about children at primary school" (T3). In 2013-2014 education years, at the same time of the basic change of the school system called ' $4+4+4$ ', English lessons in 2 nd and 3rd grades were initiated. A teacher underlined the difficulties of this period and said "The Ministry might have provided in-service trainings but maybe we have not heard" (T5). In German states, there is a compulsory in-service training program every two years but according to the statements of teachers this arrangement is not clear enough. Currently, English teachers of Germany can participate in in-service trainings of foreign language teaching for early age groups provided by the states if they request it. One of the teachers in Germany stated "We should attend two of these seminars in a year but it doesn't matter which topic so you do not have to choose English seminars. I can go to music seminar or German seminar" (G4).

As a conclusion, in Turkey English teaching approaches of the teachers are different from what is in the program. In Germany, the philosophy and the approaches of the teachers are more compatible with the programs. Also, teachers in Turkey are not well trained and supported to teach English to children and they just depend on their classroom experiences. In Germany, teachers can get in service trainings when they ask for from the ministry.

\subsection{How do English Teachers in Turkey and Germany Implement the Programs?}

In this part, implementations of the teachers are questioned and analyzed. The questions are about the adaptations of the program, language teaching approaches, teaching methods, working methods, activities, materials and evaluation methods they use in the classroom. Also, the teacher were asked how often they songs and games which is one of the important component of the primary level English program.

Both countries suggest communicative method and its activities in English programs defined as in CEFR, an internationally valid language assessment system with a course design through objectives in semantic/pragmatic rather than the traditional syntactic terms [73]. English teachers in Turkey described the most done activities in class as songs and games, but also the activities of grammar-translation and audio-lingual methods, which focus on the structure rather than communication. In Turkey there is a gap between the idealized official policy framed by MONE and the actual classroom implications because most of the teachers are unable to use communicative learning environment and also there are problems with the course books as they cannot support the communicative method [63]. The beliefs of the teachers are generally shaped by how they learnt English although in both countries almost all of the teachers started learning English when they are at secondary school. The tendency to teach English at primary level is relatively a new approach. One of the teachers in Turkey stated:

"The program actually suggests that we do not give importance to grammar, but we have to, because if the child does not have a base or if he does not know anything, they cannot talk or we cannot teach anything without knowing the grammar. ...because a child who does not know anything in writing cannot be very successful in speaking. After they do grammar, speaking can be improved. I think it should be like this and I do it like this. We listen to the texts, but I think foreign language can be learned by writing, that is what I think. I give importance to grammar and writing. ....In this case, first I teach then I give the photocopies from the sources and afterwards we listen. This is the method I use" (T3).

Another teacher also pointed out "Of course I do not want to go into the grammatical subjects but I do. You do not say simple present tense, but you have difficulties somewhere" (T5). Copland and Garton [74] state that some teaching methods such as communicative method or task-based learning (TBLT) are compulsory in the primary English language programs with changes in the education policies of the countries, but these policy decisions bring a number of problems. For example, meaning-based approaches developed for adults in the West are incompatible with local education traditions of other countries and may be contrary to the expectations of both parents and students. Although a number of trainings are often given on the imported approaches, the teachers often state that the trainings are inadequate. For this reason, there is a gap between classroom practices and policy, and teachers are able to return to familiar practices. This situation can easily be seen in the context of Turkey.

According to the teachers' perceptions in both countries, although the programs are designed as a student-centered, half of the teachers in Turkey and Germany stated that they did not have student centered classroom environment because of limited class time and the crowded classes. A teacher in Turkey said "I do not think it is student-centered. The book restricts me. It is more teacher-centered, especially if we consider second grades because the child does not know anything" (T1). For the success prediction in school some of the variables are cultural and economic capital [4]. In German states, one of the teachers underlined the cultural differences of the students and stated that it was not student-centered because of a large number of immigrant populations who learn English and it is as a third 
language besides German and their native language. Generally, teachers find themselves in a more active role. A teacher in Germany said:

"When I teach English I think it isn't what you call it student centered. It is teacher centered. We start every English lesson I say now we switch into English we sing our morning song. I talk a lot and they try to understand what I am talking about and when they talk, they only say one word or two words. When I ask something sometimes they answer in German but I think it is not student centered" (G3).

Among the activities conducted by English teachers in Turkey and the states of Germany games, songs and role plays are the most ranked. Half of the English teachers in Turkey said they had more room for dialogue, singing and gaming activities. However, the other half stated that they did not have enough time for songs and games. While doing activities, it is seen that they frequently use technology in their classes. One of the teachers in Turkey stated:

"Music and cut and paste activities, I use them very often, flash cards are actually what they see at this point, they are not as effective as the old ones, and they lost their effectiveness. Now we use more visual, especially technology" (T5).

All of the English teachers in the German states declared that they performed songs, play, rhymes/poetry and role-playing activities in their classrooms:

"We teach a lot of vocabulary through stories, songs. The songs also give you the opportunity to teach them chunks of language not only single words. We do also working with the workbook in the way up coloring things in or making little books to the stories they heard, role-plays they have to play the story themselves" (G6).

The most important difference in terms of the practices of English teachers in Turkey and Germany can be seen in the frequency of using songs and plays, which are the basic elements of the program. Half of the teachers in Turkey use songs every lesson but the other half said that they did not have time for songs and games. It would appear that in Turkey teachers use the songs mostly to entertain the children but not as a learning activity as they may believe singing is just for fun based on their experiences as students. All of the English teachers in the German states said that they used songs and games in every lesson.

The program of English in primary level needs bridging the gap between planned, taught and experienced program involving program guidelines, learning materials and the assessment $[75,76]$. In terms of materials English teachers in Turkey listed textbook and projection and teachers in the German states listed textbooks and CD/DVDs as the most frequently used materials in the class. In Turkey, there are also teachers who actively use computers and internet either the school or parents provided. There are no computers or internet in the classes of teachers in Germany. English teachers in Germany stated that they used storybooks, story cards, and textbooks with posters and cutting and pasting materials. They use songs and games more in their lessons and do not have any trouble with the materials when doing these activities. A teacher in Germany said:

"It is more of a story it is like they have a picture book they have to fold. It is just a piece of paper, you have to fold in a certain way and then they can make a mini book. We do a lot of crafts projects or something like milkshakes or fruit salad activities. We made tea in class once, two or three times prepared milkshake, fruit salad ...actual realia like vegetables, fruit, and clothes" (G6).

It appears that English teachers interviewed in Turkey have more technical support because there are computers, projections and even internet in some classes. However, this situation is of course not valid for all Turkish schools. The teachers who have technical support in their classes may still complain about lack of materials. The important point here is that the English teachers in the Germany who do not have technological equipment did not present this situation as a problem.

The course books are provided by the government and sent to schools free of charge in Turkey. Generally, teachers are not aware of the program prescribed but the course books are used to get the idea of the program. The MONE in Turkey does not approve the use of source books. However, some teachers in Turkey admitted that they used source books with the approval from the parents. One of the teachers in Turkey stated "Normally we use course books provided by the MONE, but we recommend a source book to work at home and for homework. If the parents approve them to buy, we use these books" (T1). Teachers in Germany declared that they used state-recommended course books as well as extra materials and they expressed that they could choose their course books with other English teachers in the school. In some schools in Germany, course books are not used and the program is implemented with the materials developed by the teachers. One of the teachers in Germany said:

"I think I have to adapt it. The state tells me what I have to do, how to learn English and what they have to learn at the end of the year.... Second class and at the end of the fourth class they tell you that they have to do in English" (G3).

English teachers in Turkey generally evaluate the students at the end of the unit and at the end of the term. Half of the teachers make observations during the term. Accordingly, the frequency of evaluations of the teachers in Turkey varies. It may be because of the frequency of evaluation is not clearly expressed in the English programs. English teachers in Germany evaluate twice in a term or at the end of the term. Some of the teachers in 
Germany pointed out that evaluation could be difficult because they did not test in writing and they just made observations.

In addition, there are some non-traditional methods of assessment such as projects and portfolios stated in the English programs but in both countries teachers did not mention them as evaluation methods. Only one teacher in German states expressed that she asked questions to make students self-assess themselves at the end of the lesson as a method of evaluation and she thinks that it is necessary to do it every lesson. In both countries, it is seen that English teachers evaluate students with observations.

The program policy at the primary level stress communicative competence, however, examinations are still based on grammar, vocabulary and multiple-choice [9]. The same situation can be seen in Turkey as English teachers in Turkey often stated that they conducted test exams in schools and the success of English courses was assessed according to these exams. Many teachers expressed that they did not believe these evaluations were appropriate. However, it can be said that the schools and the parents affect the evaluation methods of the teachers with their expectations. It is proven by many researches that it is related to wash back effect. One reason teachers frequently justify the using of grammar-translation methodology is directly related to preparation for English-language university entrance examinations and the influence of high-stakes assessment on teaching and learning has considerable effect on actual teaching practice and testing [77]. English teachers in the German states underlined that the tests they performed had more of visual elements than text. The number of English teachers in Turkey who use self-evaluation is also quite low and half in Germany. English teachers in Turkey stated that they did not use self-evaluation because of the limited course hours and they did not believe that the children could self-evaluate.

In conclusion there seems to be a strong tension between the beliefs of the teachers and the practices of English teachers in Turkey according to the approaches and teaching methods. Although teachers are aware of what prescribed program expect, mostly teachers' beliefs are significant in their practices. In Germany, on the other hand it can be said that teachers' beliefs are more compatible with what the program presents. Educational philosophies of these countries seem to be different because in Turkey there are traditional tendencies and they are still in practice in the classroom but in Germany teachers seem to have the same beliefs as the program suggest.

\subsection{What are the Problems English Teachers in Turkey and Germany have While Applying the Programs and What are the Recommended Solutions for These Problems?}

In this part, the problems English teachers in Turkey and Germany have during the implementation of the programs and recommended solutions for these problems were presented and analyzed. English teachers in Turkey and Germany find the content of the programs satisfactory. However, it can be said that in both countries teachers have different understanding of content. Although the English programs in both countries have a similar content due to differences in practice (such as grammar and writing teaching) it can be said that English teachers in Turkey perceive the program intensive and they think it should be revised. Some of the teachers in Turkey think that the contents of the units are not enough, and the activities should be enriched with the games. One of the teachers thinks activities in the book can be increased, "The program is weak in content. There must be more activities for this age group. The activities should not be for the sake of to be activity. The children at this age adapt easily, need to play, imagination, cartoons" (T1). English teachers in Turkey criticize that program to be unsuitable for children. "The weakness of the program is it is not suitable for the characteristics of that age because they have an unlimited imagination, we cannot imagine what they dream of. When we give them a creative activity, things are very good" (T1). Also another teacher thinks that at the 3 rd grade the content is intensive and they are forced to give new structures:

"For example, I think that the content for the 2 nd grade is ok and it is simple, but the content of the $3^{\text {rd }}$ grade is very intense. I think there are so many new structures, which are compressed into a unit, which causes children to get confused, so I find it difficult" (T6).

English teachers in Germany state that the content of the program is sufficient. One of the teachers says that the program is sufficient for children at this level:

"That's enough. Because they don't learn English in the first half of the year. First, they have to learn to read and write. We start in the second half of the year; this is enough, because many children cannot speak German. German is very difficult for them to learn English as a second language so this is enough for these children" (G2).

On the other hand, some of the English teachers in German states said that the English programs were inadequate in terms of the transition to secondary level and there needed to be done some regulations. Teaching methodology in both primary and secondary school levels has a crucial role especially for maximizing the special needs of early-starting students and for a smooth transition between primary and secondary schooling [4].

Despite the fact that the lesson hours are the same in both countries, unlike teachers in Germany, some of the teachers in Turkey claimed that course hours were not enough and could be increased and also they needed more materials. The teachers T3 and T6 in Turkey indicated that the course hours were low and could not devote enough 
time to activities "Of course I can do the activities in 20 minutes instead of 10 minutes. Children can be more active" (T3). Teacher T6 stated that "I think it's certainly not enough because I want to do activity, children want to do something a little more comfortable like pictures, but we don't have enough time to do it". Another teacher in Turkey had a self-criticism and stated:

"In fact, I can't speak in English 40 minutes of the lecture. Why is that? Because I start the first lesson in English, "Hello, how are you? What is your name?" I talk to children I ask, they answer, understand me, we meet. But I need to use Turkish at some point. For example, I say "Open the page 8" in Turkish, but I should show instead, actually let me speak for myself, it's easier for me. I can take a book and open that page, I can show it. Well, this is our weaknesses. The program may not be perfect, but $I$ can do a self-criticism. We are not able to apply much of what we learned, and I feel sorry for that. Our times have been wasted. All the exams we took and things we learned in our studies... It is us. There is no obstacle" (T4).

Also the teachers complain about not being allowed to use different materials than the ministry provide. One of the teachers in Turkey underlined the need for the materials:

"In other schools, in order to ensure that the current program is efficient, all schools must have internet and projection, because without them, if they use the textbook as an only source to implement the program, it can't be efficient. There must be standardization where this program is implemented; the physical facilities of the classes should be almost the same" (T10).

As for the evaluation process teachers in Turkey stated they had some problems about testing. A teacher in Turkey criticized not only the testing system but also every stakeholder "We have to add more to make arrangements from beginning to end because it isn't enough for children. When they have the test or when they are at the 5th grade, they don't have enough. I expect success, parents and the administration expect success, too. I give importance to grammar instead of speaking because of tests. In the exam, there is no speaking so we have we a dilemma. Since we have little time, we can't spend time for speaking (T3). Whereas teachers in Germany stated that they had no problems about evaluation.

Teachers in Turkey also complained about not getting enough support for teaching English to children. One of them said:

"We haven't been informed enough. "Did you get a seminar about this program?" You asked. No, we didn't, so no one came and said do this and that for the 2nd grade. It was just the start of a new system and a program. So we weren't supported. At least, someone like you didn't come and raise the awareness" (T4). It can be said that as Richardson [24] states the teachers may change their beliefs if there is a situation to think reflectively during their teaching experience.

In Germany, some of the teachers complained about the teachers who are not English teachers but they give English lesson. As we mentioned earlier shortage of English teachers may cause this kind of precautions in both countries. One of them stated:

"I think there can be more English lessons and different methods can be given to teachers by showing them how to do to implement the program. Especially for teachers who are not trained in English. As long as the teachers are willing to speak English they can speak but some of them didn't study English at the university. Now they speak English but they are not used to speaking in English" (G7).

As a conclusion, English teachers in Turkey suggest that English program may be more efficient with the class size of no more than 20 and more lesson hours, more in-service trainings and seminars for teaching English to children and to be allowed to use different resources. Teachers in Germany stated that they generally did not have difficulties in implementing the programs but transition to secondary school and teachers who did not study English at university were problematic. They suggest that the transition should be smooth and provide professional development for those teachers.

\section{Conclusions}

Rixon [8] warns that success of foreign language teaching depends on not only the age factor but the conditions, the methods and the program implemented and these factors can lead negative results. The language learning process of children requires accurate guidance. A study conducted in Turkey concluded that the generic teacher competences proposed by The Ministry of National Education (MONE) do not specify competences that are critical to teach English effectively and also the subject-specific teacher competences are out-of-date and do not include teacher competences for English in the second year of primary education [78]. For a successful foreign language teaching program, adequate teacher training and suitable teaching methodology are necessary to get the expected results as the findings generally show that both teachers' beliefs and how they were trained influence the implementation process $[38,61]$. According to the results obtained in this study, teachers in Germany stated that they did not have problems with the program in general especially about the materials and lesson hours which shows some indications of autonomy. However, it can be said that the problems of the primary level English program in Turkey, which started in the 4th grade in 1997, 
are still continuing. English teachers in Turkey claim that they do not have sufficient support from the education ministry for teaching English to children and experience difficulties. Their practices in class do not base on communicative approach although their stated beliefs seem to be compatible with this approach. Generally, they have grammar based activities which shows their actual beliefs are different. It seems that effective teacher training, in-service trainings and increasing the on-site training hours in faculties to make teachers more experienced are necessary for the success of teaching foreign languages in Turkey. Also the education of the present teachers in the school should have the cooperation and interdisciplinary network should be strengthened. Teachers in Turkey claimed that they needed more lesson hours although they admitted that they did not use the lesson hours effectively and their lessons were not actually communicative. Furthermore, they stated they needed different materials although they had different kinds of technological equipment in classes in general. That may show that they are not autonomous enough to use the materials effectively and depend on the course books and unit plans made for them by the ministry. On the other hand, English teachers in Germany can be said to have more communicative based lessons as they have beliefs compatible with this approach. Besides they are class teachers and they have more pedagogical knowledge on how to teach children compared to the teachers in Turkey.

There are significant shortcomings of teaching English to early age groups in English teacher training policies and programs. In Germany, teacher training policies and practices have a long history and teachers specialized in at least two disciplines as primary school teachers to give primary school English lessons and they get on-site training. Whereas in Turkey the period in terms of on-site trainings is shorter in English teacher programs in Turkey as set forth in this study and the training may not ever happen for the young age groups. In this case, a system similar to double discipline programs may be introduced, or candidate teachers can take courses related to relevant fields from universities' elective courses by reducing existing credit loads and make appropriate choices for which level group they are planning to work with. For example, if a prospective teacher studying English is planning to work with an early age group; they can choose educational material development from class teaching department, technology education from technology faculties and child psychology from psychology department.

English teachers should be empowered with primary school methodology to be effective in a communicative classroom. At least the collaboration between the class teacher and the foreign language teacher is needed to engage in planning to embed and integrate the foreign language in daily activities of the class [42,61,72].
Furthermore, the field of early foreign language learning needs more empirical research particularly on teachers' beliefs and trainings, the transition from primary to secondary education, and the use of materials. In addition, further mixed method studies with different countries can be done with other stakeholders like the students and the ministry representatives. Also, observations in classes can be done to see the implementations of the teachers to have clear ideas about foreign language teaching to children.

\section{Acknowledgements}

This article was produced from $\mathrm{PhD}$ thesis of the corresponding author.

\section{Appendix 1}

\section{Descriptive Information}

1. How long have you been teaching?

2. What sort of education have you had to teach English?

3. How many hours do you teach in a week?

4. What type of school do you teach English in?

\section{As you examine the program overall;}

1. What are the philosophies and the basic approaches of the English curriculum has that you apply now? Do you know what it is? Do you think that philosophy could have been applied to this program?

2. What are the suggested teaching approaches in the program? Do you know all of them? At which ones are you competent?

3. Is there a manual for the English program? If there is, have you checked it? In what ways is it helpful for you?

4. Do you think teaching to young learners is different from teaching English to adults? Do you think you have enough knowledge about it?

\section{While implementing the program;}

1. How do you implement the English program to your lessons? (Adaptation, direct usage) Cue: Have got any supplements except the framework of the program? (Another program, books, etc.)

2. Have you had any in service trainings, seminars or courses as a support while implementing the program?

3. Do you think the program is student centered? How would you describe role of the students in the program? 
4. While implementing the program do you have any teaching methods that you choose? What are they? How do you use them?

5. What are the main working methods that you frequently use while implementing the program? In which situation? (individual work, peer work, group work)

6. What do you do to create a positive atmosphere in the classroom while implementing the program?

7. How do you motivate your students to learn English?

8. Do you use multiple intelligence approach in your class? If yes, how do you use it? How would you describe using multiple intelligence approach in the class?

9. Do you take the individual differences in the class into account? (Learning speed, learning styles, etc.) How do you use them? How would you describe taking into account the individual differences in the class?

10. Which activities do you use in the class?

11. Which materials do you use in the class?

12. Do you use songs and games in the class? How often?

13. How often do you evaluate your students? What is the purpose of your evaluation?

14. Which methods of evaluation do you use? (Test, project, performance, etc.) Cue: Do you use peer evaluation, self-assessment, observation while evaluating?

15. Is there anything you would like to add and say?

\section{Possible problems and suggestions while implementing the program}

1. Do you think the content of the program is sufficient? In what way?

2. What are the strong points of the program?

3. What are the weak points of the program?

4. Do you think it is difficult to implement the program? Why? What kind of difficulties do you often face with during the implementation of the program?

5. What problems do you have in evaluation process?

6. What are your suggestions to use the program effectively?

7. Is there anything you would like to add and say?

\section{REFERENCES}

[1] Oyama, S. A Sensitive Period for the Acquisition of a Nonnative Phonological System. Journal of Psycholinguistic Research, Vol. 5, 261-283, 1976.

[2] Patkowski, M. S. The Sensitive Period for the Acquisition of Syntax in a Second Language. Language Learning, Vol. 30, No. 2, 1980.

[3] Pinter, A., Zandian, S. 'I don't Ever Want to Leave This Room': Benefits of Researching 'with' Children. ELT
Journal, Vol. 68, No. 1, Doi:10.1093/elt/cct057, 2014.

[4] Jaekel, N., Schurig, M., Florian, M., Ritter, M. From Early Starters to Late Finishers? A Longitudinal Study of Early Foreign Language Learning in School. Language Learning, Vol. 67, No. 3, 631-664. Doi: 10.1111/lang.12242, 2017.

[5] Cameron, L. Challenges for ELT from the Expansion in Teaching Children. ELT Journal, 57 No. 2, 105-112. Doi:https://doi.org/10.1093/elt/57.2.105, 2003.

[6] Johnson, J. S., Newport, E. L. Critical Period Effects in Second Language Learning: the Influence of Maturational state on the Acquisition of English as a Second Language. Cognitive Psychology, Vol. 21, 60-99, 1989.

[7] Muñoz, C. Exploring Young Learners' Foreign Language Learning Awareness. Language Awareness, Vol. 23 No. 1-2, 24-40, Doi: 10.1080/09658416.2013.863900, 2014.

[8] Rixon, S. Optimum Age or Optimum Conditions? Issues Related to the Teaching of Languages to Primary Age Children. British Council. Available online: https://www.academia.edu/11435939/Optimum_Age_or_O ptimum_Conditions, 2000.

[9] Baldauf Jr. R. B., Kaplan, R. B., Kamwangamalu, N, Bryant, P. Success or Failure of Primary Second/Foreign Language Programmes in Asia: What do the Data Tell Us? Current Issues in Language Planning, Vol.12 No.2, 309-323, Doi: 10.1080/14664208.2011.609715, 2011.

[10] EF English Proficiency Index. Available online: https://www.ef.com/ / /media/centralefcom/epi/download s/full-reports/v7/ef-epi-2017-english.pdf, 2017.

[11] Hoa, N. T. M., Tuan, N. Q. Teaching English in Primary Schools in Vietnam: An Overview. Current Issues in Language Planning, Vol. 8, No. 2, 162-173, Doi: 10.2167/cilp106.0, 2007.

[12] Sayer, P. Expanding Global Language Education in Public Primary Schools: The National English Programme in Mexico. Language, Culture and Curriculum, Vol. 28, No. 3, 257-275, Doi: 10.1080/07908318.2015.1102926, 2015.

[13] Zein, S. Pre-service Education for Primary School English Teachers in Indonesia: Policy Implications. Asia Pacific Journal of Education, Vol. 36 No.1, 119-134, Doi: 10.1080/02188791.2014.961899, 2016.

[14] EF English Proficiency Index for Companies http://media2.ef.com/ / / media/centralefcom/epi/downloa ds/full-reports/v5/ef-epi-2015-english.pdf, 2015.

[15] Borg, S. Teacher Cognition in Language Teaching: A Review of Research on What Language Teachers Think, Know, Believe, and Do. Language Teaching, Vol. 36, 81109, Doi: 10.1017/S0261444803001903, 2003.

[16] Pickering. A. M. Learning about University Teaching: Reflections on a Research Study Investigating Influences for Change. Teaching in Higher Education, Vol. 11, No. 3, 319-335, Doi: 10.1080/13562510600680756, 2006.

[17] Pope, M. Anticipating Teacher Thinking. In Research on Teacher Thinking: Understanding Professional Development. Eds. Calderhead, J., Denicolo, P., Day, C. Routledge: New York, 2012. 
[18] Burns, A. Starting All Over Again: From Teaching Adults to Teaching Beginners. In Teacher Learning in Language Teaching. Eds. Freeman, D. and Richardson, J. C. Cambridge University Press: Cambridge, 1996.

[19] Olson J. Teacher Influence in the Classroom: A Context for Understanding Curriculum Translation. Instructional Science. Vol. 10, 259-275, 1981.

[20] Munby, H. The Place of Teachers' Beliefs in Research on Teacher Thinking and Decision Making, and an Alternative Methodology. Instructional Science, Vol. 11, 201-225, 1982.

[21] Holt-Reynolds, D. Personal History-Based Beliefs as Relevant Prior Knowledge in Course Work. American Educational Research Journal, Vol. 29, No. 2. https://doi.org/10.3102/00028312029002325, 1992.

[22] Pajares, M. F. Teachers' Beliefs and Educational Research: Cleaning Up a Messy Construct. Review of Educational Research, Vol. 62, No. 3 https://doi.org/10.3102/00346543 $062003307,1992$.

[23] Johnson, K. E. The Emerging Beliefs and Instructional Practices of Pre-service English as a Second Language Teachers. Teaching and Teacher Education, Vol. 10, No. 4, 439-452. http://dx.doi.org/10.1016/0742-051X (94)90024-8, 1994.

[24] Richardson, V. The Role of Attitudes and Beliefs in Learning to Teach. In Handbook of Research on Teacher Education (Ed.) Sikula J. (2nd edition), 102-119. New York: Macmillan, 1996.

[25] Kennedy C. and Kennedy, J. Teacher Attitudes and Change Implementation. System, Vol. 24 No. 3, 351-360, 1996.

[26] Richards, J. C., Ho, B., Giblin, K. Learning How to Teach in RSA Cert. In Teacher Learning in Language Teaching. Eds. Freeman, D. and Richardson, J. C. Cambridge University Press: Cambridge, 1996.

[27] Clark, C. M. and Yinger R. J. Research on Teacher Thinking Source: Curriculum Inquiry, Vol. 7, No. 4, 279-304, 1977

[28] Schulz, R. E. Cultural Differences in Student and Teachers Perceptions Concerning the Role of Grammar Instruction and Corrective Feedback: USA- Colombia. Modern Languages Journal, Vol. 85, 244-258, 2001.

[29] Park M., Sung, Y.-K. Teachers' Perceptions of the Recent Curriculum Reforms and their Implementation: What can We Learn from the Case of Korean Elementary Teachers? Asia Pacific Journal of Education, Vol. 33, No. 1, 15-33, Doi: 10.1080/02188791.2012.756391, 2013.

[30] Yan, C. 'We can Only Change in a Small Way': A study of Secondary English Teachers' Implementation of Curriculum Reform in China. Journal of Educational Change, Vol.13, 431-447, Doi: 10.1007/s10833-012-9186-1, 2012.

[31] Baştürkmen, H., Loewen, S. and Ellis, R. Teachers' Stated Beliefs about Incidental Focus on Form and Their Classroom Practices. Applied Linguistics. Vol. 25, No. 2, 243-272.

[32] Clark, C. M., Peterson, P. L. Teachers' Thought Processes. Occasional Paper No. 72. Michigan State University, East Lansing. Institute for Research on Teaching, 1984.
[33] Calderhead, J. Teachers: Beliefs and Knowledge. In Handbook of educational psychology, (Eds.), Berliner D. C., Calfee, R. C (pp. 709-725). New York, NY, US: Macmillan Library Reference Usa; London, England: Prentice Hall International, 1996.

[34] Verloop, N. Van Driel, J., Meijer. P. C. Teacher Knowledge and the Knowledge Base of Teaching. International Journal of Educational Research, Vol. 35, No. 5, 441-461. Doi: 10.1016/S0883-0355(02)00003-4, 2001.

[35] Baştürkmen, H. Review of Research into the Correspondence between Language Teachers stated beliefs and practices. System, Vol. 40, 282-295. 2012

[36] Phipps, S., Borg, S. Exploring Tension between Teachers' Grammar Teaching Beliefs and Practices. System, Vol. 37, No. 3, 380-390, 2009.

[37] O'Sullivan, M. The Reconceptualization of Learner-Centered Approaches: A Namibian Case Study. International Journal of Educational Development, Vol. 24, No. 6, 585-602, 2004.

[38] Altaieb, S. R. Teachers' Perception of the English Language Curriculum in Libyan Public Schools: An Investigation and Assessment of Implementation Process of English Curriculum in Libyan Public High Schools. Phd Dissertation. University of Denver, 2013.

[39] Bulut, İ., Atabey, E. İlkokul İkinci Sınıf İngilizce Dersi Öğretim Programının Uygulamadaki Etkililiğinin Değerlendirilmesi. [The Evaluation of the Second Grade of Primary Level English Language Teaching Programme Implementation]. İnönü Üniversitesi Eğitim Fakültesi Dergisi Vol. 17, No. 3, 257-280. Doi: 10.17679/inuefd.17366404, 2016

[40] Demir, O., Duruhan, K. İlkokul 2. Sınıf İngilizce Dersi Programı Uygulamalarına İlişkin Öğretmen Görüşleri. [Teachers' Opinions on the English Language Curriculum Implementation of the 2nd Grade of Primary Education]. International Journal of New Trends in Arts, Sports \& ScienceEducation, Vol. 4 No. 3, ISSN: 2146 - 9466, 2015.

[41] Gorsuch, G. J. EFL Educational Policies and Educational Cultures: Influences on Teachers Approval of Communicative Activities. TESOL Quarterly, Vol. 34, No. 4, 675-710, 2000.

[42] Hamid, M. O., Honan, E. Communicative English in the Primary Classroom: Implications for English-in-Education Policy and Practice in Bangladesh. Language, Culture and Curriculum, Vol. 25, No. 2, 139-156, Doi: 10.1080/079083 18.2012.678854, 2012

[43] Hardman, J., A-Rahman, N. Teachers and the Implementation of a New English Curriculum in Malaysia. Language, Culture and Curriculum, Vol. 27, No. 3, 260-277, Doi: 10.1080/07908318.2014.980826, 2014.

[44] Kirgo, Y. A Case Study of Teachers' Implementation of Curriculum Innovation in English Language Teaching in Turkish Primary Education. Journal of Teaching and Teacher Education, Vol. 24, 1859-8175, 2008.

[45] Matear, A. English Language Learning and Education Policy in Chile: Can English really open doors for all? Asia Pacific Journal of Education 28:2, 131-147, Doi: 10.1080/02188790802036679, 2008. 
[46] Nunan, D. The Impact of English as a Global Language on Educational Policies and Practices in the Asia-Pacific Region. TESOL Quarterly, Vol. 37, 589-613, 2003.

[47] Pandian, A. English Language Teaching in Malaysia Today. Asia Pacific Journal of Education, Vol. 22, No. 2, 35-52, Doi: 10.1080/0218879020220205, 2002.

[48] Turkan, S. Teacher Representations of English as a Foreign Language: Case Study of Two Teachers in Turkey. Turkish Online Journal of Qualitative Inquiry Vol. 4, No. 1, 2013.

[49] Wang, C. Innovative Teaching in Foreign Language Contexts. In S. Savignon (Ed), Interpreting Communicative Language Teaching (131-153). New Haven: Yale University Press, 2002.

[50] Waters, A., Vilches, M. Factors Affecting ELT Reforms: The Case of the Philippines Basic Education Curriculum. RELC Journal, Vol. 39, 5-24, 2008.

[51] Wedell, M. Giving TESOL Change a Chance: Supporting Key Players in the Curriculum Change Process. System, Vol. 31, 439-456, 2003.

[52] Yıldıran, Ç., Tanrıseven, I. Teachers' Opinions on the English Curriculum of the 2nd Grade Primary Education. International Journal of Language Academy, Vol. 3, No.1, 210-223, 2015.

[53] Yook, C., Lee, Y. Korean EFL Teachers' Perceptions of the Impact of EFL Teacher Education upon their Classroom Teaching Practices. Asia Pacific Journal of Teacher Education, Vol. 44, No. 5, 522-536, http://dx.doi.org/10.1080/1359866X.2016.1144171, 2016.

[54] Eurydice. Germany: Primary Education. https://webgate.ec. europa.eu/fpfis/mwikis/eurydice/index.php/Germany:Teach ing_and_Learning_in_Primary_Education\#Foreign_langua ge teaching, $2015 \bar{a}$.

[55] KMK. Bericht Fremdsprachen in der Grundschule Sachstand und Konzeptionen. 2013.http://www.kmk.org/fil eadmin/Dateien/veroeffentlichungen beschluesse

/2013/2013_10_17-Fremdsprachen-in-der-Grundschule.pdf, 2013.

[56] TTKB. İlköğretim Kurumları (İlkokullar ve Ortaokullar) İngilizce Dersi $(2,3,4,5,6,7$ ve 8. Siniflar) Öğretim Program1. [English Lesson Curriculum for Primary and Secondary Level $(2,3,4,5,6,7$ and 8 grades]. http://ttkb.meb.gov.tr/www/ogretim-programlari/icerik/72, 2013.

[57] Gardner, M. Germany: New Guidelines for Teacher Training. University World News No. 45. September 21. http://www.universityworldnews.com/article.php?story $=20$ 080919095858344, 2008.

[58] Kothoff, H. G., Terhart, E. 'New' Solutions to 'Old' Problems? Recent Reforms in Teacher Education in Germany. Revista Española de Educación Comparada, Vol. 22, 73-92. ISSN: 1137-8654, 2013.

[59] Blömeke, S. Globalization and Educational Reform in German Teacher Education. International Journal of Educational Research Vol. 45, 315-324, 2007.

[60] Drew, I., Oostdam, R., van Toorenburg, H. Teachers' Experience and Perceptions of Primary EFL in Norway and the Netherlands: A Comparative Study European Journal of
Teacher Education, Vol. 30, No. 3, 319-341. Doi: 10.1080/02619760701486159, 2007.

[61] Ertl, H. \& Phillips, D. Standardization in EU Education and Training Policy: Findings from a European Research Network. Comparative Education, Vol. 42, No. 1, 77-91. Doi: 10.1080/03050060500515769, 2006.

[62] Fretwell, D. H., Wheeler, A. Turkey: Secondary Education and Training. The World Bank, Washington DC, 2001.

[63] Kırkgöz, Y. Curriculum Innovation in Turkish Primary Education. Asia-Pacific Journal of Teacher Education, Vol. 36, No. 4, 309-322, 2008.

[64] Bliesener, U. Foreign Language Teaching in Germany. In Education and Science. Collected Works Serials (022) Reports - Descriptive edited by Tapia, I., Blochmann, G. M., (141, 2-32), 1998.

[65] Eurydice. Initial Education for Teachers Working in Early Childhood and School Education. https://webgate.ec.europa .eu/fpfis/mwikis/eurydice/index.php/Germany:Initial_Educ ation_for_Teachers_Working_in_Early_Childhood_and_Sc hool_Education\#First_stage_of_teacher_training:_Studies_ at a higher_education institution, $2015 \bar{b}$.

[66] Decke-Cornill, H. We Would Have to Invent the Language We are Supposed to Teach: The Issue of English as Lingua Franca in Language Education in Germany. Language, Culture and Curriculum, Vol. 15 No. 3, 251-263. Doi:10.1080/07908310208666649, 2002.

[67] Creswell, J.W. Qualitative, Quantitative, and Mixed Methods Approaches. 3rd ed. London: Sage Publications, 2009.

[68] Miles, M.B., Huberman, A.M. Qualitative Data Analysis: An Expanded Sourcebook. 2nd ed. London: Sage Publications, 1994.

[69] Schröder, K. Eight Hundred Years of Modern Language Learning and Teaching in the German-speaking Countries of Central Europe: a Social History. The Language Learning Journal Vol. 46 No. 1, 28-39, https://doi.org/10.1080/0957 1736.2017.1382054, 2018.

[70] Enever, J., Moon, J. New Global Contexts for Teaching Primary ELT: Change and Challenge. In Young Learner English Language Policy and Implementation: International Perspectives, edited by Enever, J., Moon, J., Raman, U. 5-20. Reading, UK: Garnet Publishing, 2009.

[71] Uysal, H. H., Plakans, L, Dembovskaya, S. English Language Spread in Local Contexts: Turkey, Latvia and France. Current Issues in Language Planning, Vol. 8, No. 2, 192-207, Doi: 10.2167/cilp105.0, 2007.

[72] Komorowska, H. Organisation, Integration and Continuity in Foreign Language Learning in Primary Schools (Age 5/6 to $10 / 11$ ) edited by Doye, P., Hurrell, A. Council of Europe. Germany, 1997.

[73] Howatt, A.P.R., Smith, R. The History of Teaching English as a Foreign Language, from a British and European Perspective. Language and History, Vol. 57, No. 1, 75-95, 2014.

[74] Copland, F., Garton, S. Key Themes and Future Directions in Teaching English to Young Learners: Introduction to the Special Issue. ELT Journal, Vol. 68 No. 3, 
Doi:10.1093/elt/ccu030, 2014.

[75] Marsh, C., Willis, G. Curriculum: Alternative Approaches, Ongoing Issues. Upper Saddle River, NJ: Merrill/Prentice Hall, 2007.

[76] McKay, P. A National ESL Curriculum Framework: The ALL Projects Input. In Australian Teachers of English to Speakers of Other Languages 6th Summer School Proceedings, 20-42, 1989.

[77] Underwood, P. R. Teacher beliefs and intentions regarding the instruction of English grammar under national curriculum reforms: A Theory of Planned Behaviour Perspective. Teaching and Teacher Education, Vol. 28, No. 6, 911-925. https://doi.org/10.1016/j.tate.2012.04.004, 2012.

[78] Uztosun, M. S. Professional competences to teach English at primary schools in Turkey: a Delphi Study. European Journal of Teacher Education, Doi: 10.1080/02619768.201 $8.1472569,2018$. 